\title{
Export Competitiveness of Indian Paddy in International Market
}

\author{
J. S. Atla*, V. G. Pokharkar and D. B. Yadav \\ Department of Agricultural Economics MPKV, Rahuri, (MS), India \\ *Corresponding author
}

\begin{abstract}
A B S T R A C T
Keywords

NPC, EPR,

International

market, Indian

paddy, Competitive

Article Info

Accepted:

15 January 2021

Available Online:

10 Februarv 2021

The present study was conducted on the export competitiveness of Indian paddy in international market by using Nominal Protection Coefficient (NPC) and Export Performance Ratio (EPR). On an average the Nominal Protection Coefficient (NPC) and Export Performance Ratio were 0.62 and 11.74 respectively, it means that Indian paddy was competitive in international market during study period. On an average the Nominal Protection Coefficient (NPC) were 0.46, 0.16, 0.65, 0.55 and 0.51 for major importing countries such as Saudi Arabia, UAE, Kuwait, Yemen AR and USA respectively, it means that Indian paddy was competitive in major importing countries during study period.
\end{abstract}

\section{Introduction}

Historical evidence suggests that paddy (Oryza sativa L.) was originated either in southern parts of India or in the parts of India and Burma. Export estimates of paddy have also gone up steadily from about 13000 thousand tonnes in 2017-18. India maintains buffer stocks as per the norms specified to meet the domestic requirements. In view of the comfortable domestic stock position and surplus production, export of non-basmati paddy was liberalised and exports have gone up to 10 million tonnes during the past few years. Developing countries are the main players in the world paddy trade, accounting for 83 per cent of export and 85 per cent of imports. While there are numerous importers of paddy, the exports of paddy are limited. Just five countries Thailand, Vietnam, China, the United States and India - in decreasing order of exported quantities, accounted for about three quarters of world paddy exports.

The export of paddy is also related with the buffer stock of paddy held by the government. Because of comfortable buffer stock, India became a major exporter of paddy in 2018 . There is a strong demand for Indian paddy in the international markets. The increasing consumer demand for paddy and India's strength for production of basmati as well as non-basmati paddy, coupled with liberal export policy, and large public stock have 
created ample scope for paddy export. In recent years, the African countries have also shifted to Indian non-basmati paddy because of price competitiveness (Nethrayani et al., 2012).

\section{Materials and Methods}

The study is completely based on secondary data and the data on paddy export was collected for the period 1970-71 to 2017-18.

\section{Analytical techniques}

Nominal Protection Coefficient (NPC)

Symbolically,

$$
\mathrm{NPC}=\mathrm{Pd} / \mathrm{Pr}
$$

Where,

$\mathrm{NPC}=$ Nominal protection coefficient of paddy

$\mathrm{Pd}=$ Domestic wholesale price of paddy

$\operatorname{Pr}=$ World reference price of paddy

If the NPC is less than one, then it indicates that the commodity is competitive compared. However, if the NPC is greater than one, then the commodity is not competitive. NPC equal to one indicates that domestic price is equal to its border price (CIF or FOB) and no protection is given to the commodity.

\section{Export Performance Ratio (EPR)}

$\mathrm{EPR}=\mathrm{S}_{\mathrm{it}} / \mathrm{S}_{\mathrm{wt}}$

Where,

$\mathrm{S}_{\mathrm{it}}=$ Share of paddy in India's total export,
$\mathrm{S}_{\mathrm{wt}}=$ Share of paddy in World total export,

If EPR/RCA is greater than unity, the country has comparative advantage in export of the commodity.

\section{Results and Discussion}

\section{Export competitiveness of Indian paddy}

The export competitiveness of paddy in India was estimated by using Nominal Protection Coefficient (NPC) and Export Performance Ratio (EPR) for the period 1970-71 to 201718.

The calculations of Nominal Protection Coefficient (NPC) and Export Performance Ratio (EPR) have shown in Table 1. It was revealed from the Table 1 . that, the paddy had a comparative advantage because the values of NPC for overall study period have been found less than unity except some years such as 1973-74, 1977-78, 1978-79, 1997-98, 2001-02 and 2011-12, in this period the NPC values were recorded as greater than unity. On an average the Nominal Protection Coefficient (NPC) was 0.62 means less than unity for paddy export which indicates that the domestic prices received by the farmers in the country were lower than the international prices. The values of Export Performance Ratio for overall study period have been found more than unity except some years such as $1970-71$ to $1973-74$ and $1975-76$ to 1977 78 , in this period the EPR values were less than unity. On an average the Export Performance Ratio (EPR) was 11.74 means greater than unity for paddy export which indicates that the paddy has comparative advantage in export.

Estimated values of Nominal Protection Coefficient (NPC) showing export competitiveness of Indian paddy with major importing countries during the period 1991-92 
to 2017-18 is presented Table 2. It is observed from the Table 2 that, the paddy had a comparative advantage because the values of NPC for overall study period in major importing countries have been found less than unity. On an average the Nominal Protection Coefficient (NPC) were 0.46, 0.16, 0.65, 0.55 and 0.51 for major importing countries such as Saudi Arabia, UAE, Kuwait, Yemen AR and USA respectively, means less than unity for paddy export which indicates that the domestic prices received by the farmers in the country were lower than the international prices.

Table.1 Competitiveness of Indian Paddy

\begin{tabular}{|c|c|c|c|}
\hline Sr. No. & Year & NPC & EPR \\
\hline $\mathbf{1}$ & $1970-71$ & 0.39 & 0.73 \\
\hline $\mathbf{2}$ & $1971-72$ & 0.50 & 0.48 \\
\hline $\mathbf{3}$ & $1972-73$ & 0.80 & 0.47 \\
\hline $\mathbf{4}$ & $1973-74$ & 1.57 & 0.39 \\
\hline $\mathbf{5}$ & $1974-75$ & 0.09 & 1.62 \\
\hline $\mathbf{6}$ & $1975-76$ & 0.51 & 0.76 \\
\hline $\mathbf{7}$ & $1976-77$ & 0.16 & 0.97 \\
\hline $\mathbf{8}$ & $1977-78$ & 3.36 & 0.38 \\
\hline $\mathbf{9}$ & $1978-79$ & 1.01 & 2.85 \\
\hline $\mathbf{1 0}$ & $1979-80$ & 0.60 & 6.24 \\
\hline $\mathbf{1 1}$ & $1980-81$ & 0.91 & 8.31 \\
\hline $\mathbf{1 2}$ & $1981-82$ & 0.20 & 17.00 \\
\hline $\mathbf{1 3}$ & $1982-83$ & 0.11 & 12.98 \\
\hline $\mathbf{1 4}$ & $1983-84$ & 0.31 & 7.11 \\
\hline $\mathbf{1 5}$ & $1984-85$ & 0.31 & 5.53 \\
\hline $\mathbf{1 6}$ & $1985-86$ & 0.15 & 12.72 \\
\hline $\mathbf{1 7}$ & $1986-87$ & 0.38 & 10.06 \\
\hline $\mathbf{1 8}$ & $1987-88$ & 0.21 & 15.79 \\
\hline $\mathbf{1 9}$ & $1988-89$ & 0.31 & 11.15 \\
\hline $\mathbf{2 0}$ & $1989-90$ & 0.29 & 9.40 \\
\hline $\mathbf{2 1}$ & $1990-91$ & 0.38 & 8.70 \\
\hline $\mathbf{2 2}$ & $1991-92$ & 0.23 & 12.58 \\
\hline $\mathbf{2 3}$ & $1992-93$ & 0.24 & 12.70 \\
\hline $\mathbf{2 4}$ & $1993-94$ & 0.24 & 13.33 \\
\hline $\mathbf{2 5}$ & $1994-95$ & 0.41 & 10.12 \\
\hline $\mathbf{2 6}$ & $1995-96$ & 0.41 & 29.94 \\
\hline $\mathbf{2 7}$ & $1996-97$ & 0.54 & 18.64 \\
\hline $\mathbf{2 8}$ & $1997-98$ & 1.18 & 18.27 \\
\hline $\mathbf{2 9}$ & $1998-99$ & 0.42 & 25.67 \\
\hline $\mathbf{3 0}$ & $1999-00$ & 0.45 & 14.26 \\
\hline $\mathbf{3 1} \mathbf{3 2}$ & $2000-01$ & 0.60 & 14.51 \\
\hline $\mathbf{3 3}$ & $2001-02$ & 1.87 & $\mathbf{E P R}$ \\
\hline $\mathbf{3 4}$ & $2002-03$ & 0.66 & 22.44 \\
\hline $\mathbf{3 5}$ & $2004-04-05$ & 0.69 & 15.06 \\
\hline $\mathbf{3 6}$ & $2005-06$ & 0.75 & 14.90 \\
\hline & & & \\
\hline
\end{tabular}




\begin{tabular}{|c|c|c|c|}
\hline $\mathbf{3 7}$ & $2006-07$ & 0.99 & 14.09 \\
\hline $\mathbf{3 8}$ & $2007-08$ & 0.33 & 18.31 \\
\hline $\mathbf{3 9}$ & $2008-09$ & 0.29 & 10.66 \\
\hline $\mathbf{4 0}$ & $2009-10$ & 0.31 & 8.66 \\
\hline $\mathbf{4 1}$ & $2010-11$ & 0.80 & 6.98 \\
\hline $\mathbf{4 2}$ & $2011-12$ & 1.05 & 9.93 \\
\hline $\mathbf{4 3}$ & $2012-13$ & 0.71 & 15.66 \\
\hline $\mathbf{4 4}$ & $2013-14$ & 0.63 & 19.20 \\
\hline $\mathbf{4 5}$ & $2014-15$ & 0.55 & 18.97 \\
\hline $\mathbf{4 6}$ & $2015-16$ & 0.59 & 17.02 \\
\hline $\mathbf{4 7}$ & $2016-17$ & 0.85 & 14.93 \\
\hline $\mathbf{4 8}$ & $2017-18$ & 0.50 & 20.31 \\
\hline & Average & $\mathbf{0 . 6 2}$ & $\mathbf{1 1 . 7 4}$ \\
\hline
\end{tabular}

Table.2 Competitiveness of Indian paddy with major importing countries

\begin{tabular}{|c|l|c|c|c|c|c|}
\hline \multirow{2}{*}{$\begin{array}{c}\text { Sr. } \\
\text { No. }\end{array}$} & Year & \multicolumn{5}{|c|}{ Nominal Protection Coefficient (NPC) } \\
\hline $\mathbf{1}$ & $1991-92$ & Saudi Arabia & UAE & Kuwait & Yemen AR & USA \\
\hline $\mathbf{2}$ & $1992-93$ & 0.76 & 0.09 & 0.78 & 0.39 & 0.14 \\
\hline $\mathbf{3}$ & $1993-94$ & 0.42 & 0.07 & 0.16 & 0.40 & 0.14 \\
\hline $\mathbf{4}$ & $1994-95$ & 0.35 & 0.05 & 0.20 & 0.60 & 0.13 \\
\hline $\mathbf{5}$ & $1995-96$ & 0.47 & 0.06 & 0.12 & 0.20 & 0.13 \\
\hline $\mathbf{6}$ & $1996-97$ & 0.41 & 0.09 & 0.20 & 0.53 & 0.16 \\
\hline $\mathbf{7}$ & $1997-98$ & 0.41 & 0.12 & 0.22 & 0.34 & 0.23 \\
\hline $\mathbf{8}$ & $1998-99$ & 0.35 & 0.10 & 0.30 & 1.07 & 0.23 \\
\hline $\mathbf{9}$ & $1999-00$ & 0.47 & 0.08 & 0.26 & 0.76 & 0.23 \\
\hline $\mathbf{1 0}$ & $2000-01$ & 0.43 & 0.09 & 0.30 & 0.61 & 0.22 \\
\hline $\mathbf{1 1}$ & $2001-02$ & 0.51 & 0.08 & 0.38 & 0.72 & 0.20 \\
\hline $\mathbf{1 2}$ & $2002-03$ & 0.65 & 0.07 & 0.47 & 0.67 & 0.18 \\
\hline $\mathbf{1 3}$ & $2003-04$ & 0.81 & 0.06 & 0.53 & 0.78 & 0.20 \\
\hline $\mathbf{1 4}$ & $2004-05$ & 0.54 & 0.16 & 0.38 & 0.66 & 0.21 \\
\hline $\mathbf{1 5}$ & $2005-06$ & 0.38 & 0.24 & 0.45 & 0.43 & 0.23 \\
\hline $\mathbf{1 6}$ & $2006-07$ & 0.44 & 0.16 & 0.40 & 0.70 & 0.24 \\
\hline $\mathbf{1 7}$ & $2007-08$ & 0.52 & 0.14 & 0.40 & 0.57 & 0.28 \\
\hline $\mathbf{1 8}$ & $2008-09$ & 0.25 & 0.09 & 0.24 & 0.47 & 0.35 \\
\hline $\mathbf{1 9}$ & $2009-10$ & 0.25 & 0.12 & 0.21 & 0.35 & 0.33 \\
\hline $\mathbf{2 0}$ & $2010-11$ & 0.32 & 0.14 & 0.40 & 0.54 & 0.39 \\
\hline $\mathbf{2 1}$ & $2011-12$ & 0.44 & 0.18 & 0.20 & 0.73 & 0.42 \\
\hline $\mathbf{2 2}$ & $2012-13$ & 0.51 & 0.28 & 0.37 & 0.52 & 0.42 \\
\hline $\mathbf{2 3}$ & $2013-14$ & 0.37 & 0.51 & 0.57 & 0.54 & 0.44 \\
\hline $\mathbf{2 4}$ & $2014-15$ & 0.42 & 0.28 & 0.31 & 0.46 & 0.40 \\
\hline $\mathbf{2 5}$ & $2015-16$ & 0.46 & 0.26 & 0.24 & 0.33 & 0.37 \\
\hline $\mathbf{2 6}$ & $2016-17$ & 0.54 & 0.32 & 0.36 & 0.52 & 0.36 \\
\hline $\mathbf{2 7}$ & $2017-18$ & 0.56 & 0.31 & 0.37 & 0.49 & 0.35 \\
\hline Grand Total & $\mathbf{1 2 . 3 4}$ & $\mathbf{4 . 2 7}$ & $\mathbf{9 . 1 1}$ & $\mathbf{1 4 . 8 3}$ & $\mathbf{7 . 1 9}$ \\
\hline Average & $\mathbf{0 . 4 6}$ & $\mathbf{0 . 1 6}$ & $\mathbf{0 . 6 5}$ & $\mathbf{0 . 5 5}$ & $\mathbf{0 . 5 1}$ \\
\hline & & & & & & \\
\hline
\end{tabular}


From the forgoing discussion, it is noted that, the values of Nominal Protection Coefficient (NPC) in paddy were less than unity over a period of 27 years for all the important importing countries indicating highly competitiveness of Indian paddy for export in international market. The NPC was lowest i.e. below 0.50 for Saudi Arabia and UAE for overall period i.e. 1991-92 to 2017-18 indicating the highly export competitiveness of these two countries. The similar results were noted by Makama et al., (2016) and Yamini (2019). The hypothesis viz; Indian paddy are competitive in the international market has been proved.

In conclusion,

The NPC is less than one in almost all the years. This indicates that paddy enjoys competitive advantage in the international market.

The EPR is greater than one in almost all the years. This indicates that paddy enjoys competitive advantage in the international market.

\section{References}

Kanaka, S. and Chinnadurai, M. 2015. A study of export competitiveness of groundnut in India. Global Journal of
Advanced Research, 2 (2): 512-520.

Kumar Rai, A.B. and Mathura Rai. 2008. Export of cucumber and gherkin from India: Performance, destinations, competitiveness and determinants. Agricultural Economics Research Review, 21: 130-138.

Kumar, A., Ali, J. and Singh, H. 2001. Trade in livestock products in India: Trends, performance and competitiveness. Indian Journal of Agricultural Economics., 56 (4): 653-67.

Kumar, N.R., Rai, A.B. and M. Rai. 2008. Export of cucumber and gherkin from India: Performance, destinations, competitiveness and determinants. Agric. Econ.Res. Rev., 21:130-38.

Mohalkar, S.S. 2005. Export performance and competitiveness of rice in India. M.Sc. (Agri.) thesis PDKV, Akola, Maharashtra.

Myneni Yamini. 2019. Export performance and competitiveness of cotton of India. M.Sc. thesis (Unpublished) MPKV, Rahuri, Maharashtra.

Satishkumar, M., Harishkumar, H.V., Ramesh, V. and Rangegowda, R. 2016. Growth, export performance and competitiveness of basmati and nonbasmati rice of India-an Markov Chain Approach. IJAEB, 9(2): 305-311.

\section{How to cite this article:}

Atla, J. S., V .G. Pokharkar and Yadav, D. B. 2021. Export Competitiveness of Indian Paddy in International Market. Int.J.Curr.Microbiol.App.Sci. 10(02): 1829-1833. doi: https://doi.org/10.20546/ijcmas.2021.1002.216 